\title{
PROFILE OF PULMONARY TUBERCULOSIS TREATMENT IN INPATIENTS WITH COVID-19 HISTORY STATUS AT PASAR MINGGU REGIONAL GENERAL HOSPITAL
}

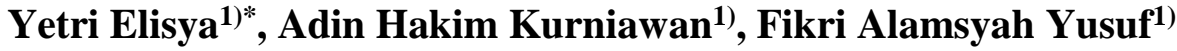 \\ ${ }^{1}$ Jurusan Farmasi, Politeknik Kesehatan Kemenkes Jakarta II, J1. Percetakan Negara \\ No.23 Jakarta Pusat, 10560, Indonesia \\ *E-mail: yetri.elisya@poltekkesjkt2.ac.id
}

Submitted: September $27^{\text {th }}, 2021$; Accepted: December $14^{\text {th }}, 2021$

https://doi.org/10.36525/sanitas.2021.16

\begin{abstract}
Pulmonary tuberculosis (TB) is caused by Mycobacterium tuberculosis, which attacks the respiratory system. In the midst of the soaring Covid-19 virus outbreak, TB patients are patients who should be more vigilant about the outbreak. GTN (Global Tuberculosis Network) describes that out of 49 patients with TB status, about 26 patients suffering from TB were then exposed to Covid-19. The purpose is to determine profile of pulmonary tuberculosis treatment in inpatients with Covid-19 history status at Pasar Minggu Regional General Hospital during the May 2020-May 2021 period. The method of the study is quantitative descriptive analysis with a retrospective method, which is to take primary data from the patient's medical record. The result shows that the total number of patients was 22 . The most common gender was male at $12(54.55 \%)$. The average patient weight is $38-54 \mathrm{~kg}$, with a number of 11 people $(50 \%)$. The most common type of patient is a new patient with 10 people $(45.45 \%)$. The most treated category was Category II, with 12 people $(54.54 \%)$. The three-tablet pattern is the most commonly prescribed.4KDT and three tablets. 2KDT and four tablets. 4KDT plus four tablets. 2KDT has the same proportion of 4 prescribing (18.18\%). The most prescribed KDT pattern of ketogori 2 is 3 tablets 4 KDT $+750 \mathrm{mg}$ streptomycin inj \& 3 tablets 2KDT + 3 tablets ethambutol, as much as 9 prescriptions (40.90\%). Medications for Covid-19 patients are most commonly prescribed in conjunction with tuberculosis drugs, namely vitamins and minerals, as many as 56 drug items $(42.42 \%)$.
\end{abstract}

Keywords : covid-19, treatment, tuberculosis

This is an open access journal, and articles are distributed under the terms of the Creative Commons Attribution-Non Commercial-Share Alike 4.0 License, which allows others to remix, tweak, and build upon the work non-commercially, as long as appropriate credit is given and the new creations are licensed under the identical terms.

(C)2021 Sanitas

Yetri E, Adin HK, Fikri AY | 172 
SANITAS: JURNAL TEKNOLOGI DAN SENI KESEHATAN

ISSN : 1978-8843 (PRINT) / 2615-8647 (ONLINE)

Vol. $12(2), 2021: 172$ - 185

\title{
PROFIL PENGOBATAN TUBERKULOSIS PARU PADA PASIEN RAWAT INAP DENGAN STATUS RIWAYAT COVID-19 DI RUMAH SAKIT UMUM DAERAH PASAR MINGGU
}

\begin{abstract}
ABSTRAK
Penyakit tuberkulosis (TB) paru disebabkan oleh bakteri Mycobacterium tuberculosis yang menyerang sistem pernafasan. Di tengah-tengah kasus melonjaknya wabah virus Covid-19, pasien TB adalah pasien yang harus lebih mewaspadai diri dari wabah tersebut. GTN (Global Tuberculosis Network) menggambarkan bahwa dari 49 pasien dengan status TB, sekitar 26 pasien menderita TB paru kemudian terpapar Covid-19. Penelitian ini bertujuan untuk mengetahui Profil Pengobatan Tuberkulosis Paru Pada Pasien Rawat Inap dengan Status Riwayat Covid-19 di Rumah Sakit Umum Daerah Pasar Minggu Periode Mei 2020-Mei 2021. Metode penelitian ini adalah analisa deskriptif kuantitatif dengan metode retrospektif yaitu dengan mengambil data primer dari rekam medik pasien. Terdapat pasien seluruhnya berjumlah 22 orang. Jenis kelamin terbanyak adalah laki-laki yaitu 12 orang $(54,55 \%)$. Usia pasien terbanyak adalah $>60$ tahun dengan jumlah 6 orang $(27,27 \%)$, dan berat badan pasien terbanyak adalah $38-54 \mathrm{~kg}$ dengan jumlah 11 orang (50\%). Tipe penderita terbanyak adalah pasien baru dengan jumlah 10 orang $(45,45 \%)$. Kategori pengobatan terbanyak adalah Kategori II dengan jumlah 12 orang $(54,54 \%)$. Pola KDT kategori 1 paling banyak diresepkan adalah pola 3 tablet 4KDT \& 3 tablet 2KDT dan 4 tablet 4 KDT \& 4 tablet 2KDT memiliki proporsi yang sama yaitu sebanyak 4 peresepan $(18,18 \%)$. Pola KDT ketogori 2 terbanyak diresepkan adalah 3 tablet 4KDT $+750 \mathrm{mg}$ streptomisin inj \& 3 tablet 2KDT +3 tablet ethambutol sebanyak 9 peresepan (40,90\%). Obat-obatan untuk pasien Covid-19 yang paling sering diresepkan bersamaan dengan OAT yaitu vitamin dan mineral sebanyak 56 jenis obat $(42,42 \%)$.
\end{abstract}

Kata Kunci : covid-19, pengobatan, tuberkulosis

\section{PENDAHULUAN}

Tuberkulosis paru (TB paru) masih menjadi permasalahan kesehatan yang serius di Indonesia sampai sekarang ini. Bersamaan dengan melonjaknya wabah corona virus (Covid-19), pasien TBC adalah pasien yang harus lebih mewaspadai diri terhadap wabah tersebut.(1) Efek langsung dan tidak langsung dari wabah virus ini pada program TB telah mengakibatkan peningkatan beban TB di daerah yang terkena dampak di tahun-tahun berikutnya.(2) GTN (Global Tuberculosis Network) merupakan salah satu program jaringan internasional yang memfokuskan salah satunya pada masalah TB. GTN menggambarkan bahwa dari 49 pasien dengan status TB, sekitar 14 pasien (28,5\%) tidak terdiagnosis Covid-19 atau sebaliknya sekitar 26 pasien (53\%) menderita TB kemudian terpapar Covid-19.(3)

Layanan TB termasuk pada sekian banyak layanan lainnya yang terganggu oleh pandemi COVID-19 pada tahun 2020, tetapi efeknya terhadap TB sangat parah. Sejumlah 1,5 juta penderita meninggal karena TB pada tahun 2020 (sebanyak 214.000 
SANITAS: JURNAL TEKNOLOGI DAN SENI KESEHATAN

ISSN : 1978-8843 (PRINT) / 2615-8647 (ONLINE)

Vol. 12 (2), 2021 : 172 - 185

di antara penderita tersebut HIV-positif). Peningkatan kematian akibat TB terutama

terjadi di 30 negara dengan kasus TB tertinggi. Proyeksi pemodelan WHO menunjukkan jumlah orang yang menderita TB dan meninggal akibat penyakit ini dapat jauh lebih tinggi pada tahun 2021 dan 2022. (3)

Sistem pelayanan TB rawat inap berdasarkan patient oriented harus menjadi pilihan perawatan di rumah sakit sesuai tatalaksana TB pada masa tanggap darurat pandemi COVID-19. Hal ini untuk meminimalkan potensi penularan COVID-19 terhadap pasien TB dengan status pasien Orang Dalam Pantauan (ODP), Pasien Dalam Pengawasan (PDP) dan pasien terkonfirmasi COVID-19. Penderita TB dapat diberikan anti-TB (OAT) pada jangka waktu tertentu sehingga stok OAT harus tetap tersedia. Pola penatalaksaan untuk pengobatan TB harus tetap berjalan, penderita diupayakan untuk tidak sering mengunjungi fasyankes TB untuk mengambil OAT. Adanya obat untuk mengatasi efek samping pengobatan juga harus tersedia. Dengan semua pola tersebut, diharapkan profil pengobatan TB di tengah pandemi tetap rasional.(4)

Protokol terapi pasien TB yang terinfeksi Covid-19 secara umum mirip halnya dengan sistem pengobatan TB, yaitu dibagi menjadi 2 tahap pengobatan. Pada dua bulan pertama disebut dengan tahap intensif dan sisanya sebagai tahap lanjutan. Prinsip dasar penatalaksanaan TB adalah minimal 3 macam obat pada tahap intensif awal dan dilanjutkan dengan 2 macam obat pada fase lanjutan. Menurut penatalaksanaan TB, terdapat standar dan pemantauan pengobatan TB untuk semua penderita. Pada penderita TB paru pertama kali, OAT harus diminum rutin selama 6 bulan secara berkelanjutan. Jika pengobatan terputus (tidak sampai enam bulan), penderita beresiko kambuh kembali dan kuman tuberkulosis menjadi resisten. (5) Permasalahan yang terjadi pada terapi TB merupakan keadaan yang dialami oleh penderita terkait minum obat. Hal ini didata oleh seorang Apoteker dan tenaga medis lainnya yang bertanggung jawab terhadap monitoring program TB paru serta memastikan bahwa layanan TB tetap berjalan. Tujuan analisis masalah terapi obat salah satunya adalah identifikasi penggunaan obat yang benar-benar memenuhi rasionalitas pasien yang terdapat pada: tepat indikasi, tepat jenis obat, tepat dosis, aman, efektif serta menjamin kepatuhan pasien.(6) 
SANITAS: JURNAL TEKNOLOGI DAN SENI KESEHATAN

ISSN : 1978-8843 (PRINT) / 2615-8647 (ONLINE)

Vol. 12 (2), 2021 : 172 - 185

Pada penelitian ini, peneliti hanya mengidentifikasi obat TB berdasarkan pola peresepan obat, serta kebutuhan terapi obat tambahan pada pasien TB dengan infeksi Covid-19. Berdasarkan survei pendahuluan yang dilakukan dengan wawancara dari pihak Instalasi Farmasi RSUD Pasar Minggu, rumah sakit tersebut merupakan rumah sakit rujukan Covid-19 di Indonesia. Selain itu RSUD Pasar Minggu juga melayani dan menangani berbagai masalah kesehatan, salah satunya penyakit tuberkulosis.

\section{METODE PENELITIAN}

Desain penelitian ini berupa analisa deskriptif kuantitatif dengan metode retrospektif yaitu mengambil data sekunder dari rekam medik pasien TB yang telah terjadi pada waktu yang lalu pada pasien Covid-19 di Rumah Sakit Umum Daerah Pasar Minggu Periode Mei 2020-Mei 2021.

Populasi penelitian ini yaitu seluruh data rekam medis yang mengandung obat tuberkulosis pada pasien rawat inap Covid-19 di RSUD Pasar Minggu. Jenis pengambilan sampel pada penelitian ini adalah non probability sampling yaitu memberi peluang atau kesempatan tidak sama bagi setiap unsur atau anggota populasi untuk dipilih menjadi sampel. Teknik pengambilan sampel berupa total sampling, yaitu dilakukan dengan mengambil keseluruhan sampel yang sesuai kriteria inklusi dan eksklusi. Kriteria inklusinya adalah Pasien TB paru dengan status riwayat Covid-19 berusia >15 tahun dan pasien TB paru dengan status riwayat Covid-19 yang dirawat inap selama periode Mei 2020-Mei 2021, sedangkan kriteria eksklusinya adalah rekam medis yang tidak lengkap dan tidak jelas.

\section{HASIL DAN PEMBAHASAN}

\section{HASIL}

Tabel 1 menunjukkan proporsi pasien TB terinfeksi Covid-19 jenis kelamin laki-laki sebanyak 12 pasien (54,55\%) sebanding dengan perempuan (45,45\%). Distribusi usia pasien TB dengan infeksi Covid-19 terbanyak pada usia >60 tahun sebanyak 6 pasien $(27,27 \%)$ dengan berat badan 38-54 kg sebanyak 11 pasien $(50 \%)$. 
SANITAS: JURNAL TEKNOLOGI DAN SENI KESEHATAN

ISSN : 1978-8843 (PRINT) / 2615-8647 (ONLINE)

Vol. 12 (2), 2021 : 172 - 185

Tabel 1.Karakteristik demografi pasien TB dengan infeksi Covid-19

\begin{tabular}{llcc}
\hline No. & Karakteristik Pasien & Jumlah Pasien $(\mathrm{n}=22)$ & Persentase \\
\hline 1. & Jenis Kelamin & 12 & \\
& Laki-laki & 10 & 54,54 \\
& Perempuan & & 45,45 \\
\hline 2. & Usia & 1 & 4,55 \\
& $16-20$ tahun & 3 & 13,63 \\
& $21-30$ tahun & 3 & 13,63 \\
& $31-40$ tahun & 5 & 22,72 \\
& $41-50$ tahun & 4 & 18,18 \\
& $51-60$ tahun & 6 & 27,27 \\
& $>60$ tahun & & \\
& Berat Badan & 11 & 50,0 \\
& $38-54 \mathrm{~kg}$ & 7 & 31,82 \\
& $55-70 \mathrm{~kg}$ & 4 & 18,18 \\
\hline
\end{tabular}

Tabel 2 menunjukkan pasien TB terinfeksi Covid-19 berdasarkan tipe penderita terbanyak adalah pasien dengan kategori I $(45,45 \%)$ dari jenis dengan kasus baru sebanyak 10 pasien $(45,45 \%)$.

Tabel 2.Tipe penderita dan kategori pengobatan

\begin{tabular}{lcc}
\hline \multirow{2}{*}{ Tipe Penderita } & \multicolumn{2}{c}{ Kategori Pengobatan } \\
\cline { 2 - 3 } & Kategori I & Kategori II \\
\hline Baru & 10 & 0 \\
Kambuh & 0 & 6 \\
Pindahan & 0 & 1 \\
Pengobatan Setelah Putus & 0 & 4 \\
Berobat (Default) & 0 & 1 \\
Pengobatan Setelah Gagal & 10 & 12 \\
\hline Jumlah & $45,45 \%$ & $54,55 \%$ \\
\hline Persentase & &
\end{tabular}

Pada tabel 3 dapat diketahui bahwa Kombinasi Obat Antituberkulosis (OAT) berserta dosisnya yang paling banyak adalah peresepan Kombinasi Dosis Tetap (KDT) kategori 2 yaitu sebanyak 12 orang (54,55\%), sedangkan kategori 1 hanya 10 orang $(45,45 \%)$. Pada pola KDT kategori 1 peresepan tahap intensif dan tahap pola 3 tablet 4 KDT \& 3 tablet 2 KDT dan 4 tablet 4 KDT \& 4 tablet 2KDT memiliki proporsi yang 
SANITAS: JURNAL TEKNOLOGI DAN SENI KESEHATAN

ISSN : 1978-8843 (PRINT) / 2615-8647 (ONLINE)

Vol. 12 (2), 2021 : 172 - 185

sama yaitu sebanyak 4 peresepan $(18,18 \%)$. Pola KDT kategori 2 terbanyak diresepkan adalah 3 tablet 4 KDT $+750 \mathrm{mg}$ injeksi streptomisin \& 3 tablet 2 KDT +3 tablet ethambutol sebanyak 9 peresepan $(40,90 \%)$.

Tabel 3. Kombinasi Obat Antituberkulosis (OAT) beserta dosis yang diberikan kepada pasien

\begin{tabular}{|c|c|c|}
\hline Dosis OAT Tahap Intensif dan Lanjutan & $\begin{array}{c}\text { Jumlah } \\
\text { Peresepan (R) }\end{array}$ & Persentase $(\%)$ \\
\hline Tahap Intensif dan Tahap lanjutan Kategori 1 & 10 & 45,45 \\
\hline 3 tablet 4 KDT \& 3 tablet 2 KDT & 4 & 18,18 \\
\hline 4 tablet 4 KDT \& 4 tablet 2 KDT & 4 & 18,18 \\
\hline 5 tablet 4 KDT \& 5 tablet 2 KDT & 2 & 9,09 \\
\hline Tahap Intensif dan Tahap lanjutan Kategori 2 & 12 & 54,55 \\
\hline $\begin{array}{l}3 \text { tab } 4 \mathrm{KDT}+750 \mathrm{mg} \text { streptomisin inj } \& 3 \text { tab } 2 \mathrm{KDT}+3 \text { tab } \\
\text { ethambutol }\end{array}$ & 9 & 40,90 \\
\hline $\begin{array}{l}4 \text { tab } 4 \text { KDT }+1000 m g \text { streptomisin inj \& } 4 \text { tab } 2 \mathrm{KDT}+4 \\
\text { tab ethambutol }\end{array}$ & 2 & 9,09 \\
\hline $\begin{array}{l}5 \text { tab } 4 \mathrm{KDT}+1000 \mathrm{mg} \text { streptomisin inj \& } 5 \text { tab } 2 \mathrm{KDT}+5 \\
\text { tab ethambutol }\end{array}$ & 1 & 4,54 \\
\hline Total & 22 & 100 \\
\hline
\end{tabular}

Pada tabel 4 dapat diketahui bahwa obat-obatan untuk pasien TB dengan status Covid-19 yang paling sering diresepkan bersamaan dengan OAT adalah vitamin \& mineral sebanyak 56 peresepan $(42,42 \%)$. Pada peresepan multivitamin pasien mendapatkan obat multivitamin minimal 2-3 jenis obat, demikian pula pada peresepan antibiotik hampir keseluruhan pasien covid 100\% mendapatkan tambahan jenis antibiotik dengan pola peresepan 1-2 jenis obat per pasiennya.

Tabel 4. Obat-obatan untuk pasien Covid-19 yang paling sering diresepkan bersamaan dengan OAT

\begin{tabular}{clcc}
\hline No. & Kelas Terapi & Jumlah Peresepan (R/) & Persentase (\%) \\
\hline 1. & Vitamin dan mineral & 56 & 42,10 \\
2. & Antibiotik & 25 & 18,79 \\
3. & Antiviral & 17 & 12,78 \\
4. & Gangguan Saluran cerna & 20 & 15,04 \\
5. & Analgetik & 15 & 11,29 \\
\hline & Total Peresepan & 133 & 100 \\
\hline
\end{tabular}




\section{PEMBAHASAN}

Berdasarkan hasil pengumpulan data yang didapatkan dari rekam medis pasien Tuberkulosis (TB) paru dengan status riwayat Covid-19 yang menjalani proses rawat inap di RSUD pasar minggu periode bulan Mei 2020-Mei 2021 didapat total pasien sebanyak 22 orang. Jumlah pasien disini sangat sedikit, hal ini kemungkinan karena pasien lainnya dirawat di Wisma Atlit. Tabel 1 menunjukkan pasien TB paru dengan jenis kelamin terbanyak adalah laki-laki berjumlah 12 orang $(54,55 \%)$ dibanding pasien perempuan dengan jumlah 10 orang $(45,45 \%)$. Penelitian ini sejalan dengan Gao $\mathrm{Y}$, et.all (2021) dengan hasil proporsi laki-laki dengan riwayat TB sebanyak 18 pasien $(4,90 \%)$.(8) Penelitian lain yang dilakukan oleh Wan, et.al (2020) pasien covid dengan riwayat komorbid paling terbanyak diderita oleh pasien laki-laki dengan persentase sebesar 46,70\%.(9) Hasil tersebut sesuai dengan hasil penelitian yang dilakukan oleh Tadolini, et al (2020) yang menyatakan bahwa penderita TB paru pada pasien Covid19 lebih banyak terjadi pada laki-laki daripada perempuan. Belum ada laporan tentang alasan kecendrungan laki-laki yang terinfeksi Covid-19 dengan status komorbid tuberkulosis melainkan terjadinya perbedaan biologis dalam penyakit dan presentasi penyakit TB sebelum terinfeksi covid-19 yang secara kebetulan mendapatkan keperawatan dirumah sakit.(2)

Usia pasien yang menderita TB pada pasien Covid-19 tertinggi pada usia $>60$ tahun sebanyak 6 orang (27,27\%). Penelitian ini sejalan dengan Liu, et.all (2020) dimana usia paling banyak pada pasien TB dengan Covid-19 adalah usia 48-69 tahun $(16,4 \%) .(8)$ Kategori usia menjadi salah satu kategori yang rentan terserang penyakit dikarenakan sistem kekebalan tubuhnya melemah seiring dengan pertambahan usia.(10) Status gizi pasien dilihat dari berat badan yang diukur pada saat pasien terdiagnosis TB ternyata selisih antar berat badan jauh berbeda jumlahnya sehingga berat badan berpengaruh terhadap risiko untuk menjadi TB. Menurut Permenkes No. 67 Tahun 2014 tentang penanggulangan tuberkulosis, berat badan yang digunakan untuk menyesuaikan dosis terdapat 5 kelompok yaitu $30-37 \mathrm{~kg}, 38-54 \mathrm{~kg}, 55-70 \mathrm{~kg}$, dan lebih dari $71 \mathrm{~kg} .(11)$ Dari hasil penelitian didapatkan berat badan $30-37 \mathrm{~kg}$ 
SANITAS: JURNAL TEKNOLOGI DAN SENI KESEHATAN

ISSN : 1978-8843 (PRINT) / 2615-8647 (ONLINE)

Vol. $12(2), 2021$ : 172 - 185

sebanyak 0 pasien (0\%), 38-54 kg sebanyak 11 pasien (50\%), dan berat badan 55-70

kg sebanyak 7 pasien $(31,81 \%)$, dan $>71 \mathrm{~kg}$ sebanyak 4 pasien $(18,18 \%)$.

Pada tabel 2 merupakan pengelompokkan pasien TB paru pada pasien Covid19 berdasarkan riwayat pengobatan, apakah pasien tersebut pernah terinfeksi sebelumnya atau pasien baru yang terinfeksi tuberkulosis. Pasien dengan kasus terbanyak merupakan tipe pasien kategori 2 dengan jumlah 12 orang (54,55\%). Resistensi obat lebih mungkin berkembang pada pasien yang telah diobati sebelumnya (yaitu pasien yang telah dirawat lebih dari satu bulan) yang terus menjadi atau yang menjadi Bakteri Tahan Asam (BTA) positif. Idealnya, semua pasien yang dirawat sebelumnya atau kategori 2 harus dinilai untuk kerentanan obat sebelum memulai pengobatan TB. Namun, dalam pengaturan di mana akses kualitas jenis obat yang digunakan terbatas, sehingga kementerian kesehatan merekomendasikan protokol standar pelayanan pengobatan TB di masa pandemi Covid-19.(12)

Pada tabel 3 dapat diketahui bahwa kombinasi OAT berserta dosisnya yang paling sering digunakan adalah peresepan Kombinasi Dosis Tunggal (KDT) kategori 2 yaitu sebanyak 12 peresepan (54,55\%). Pada pola KDT kategori 1 peresepan tahap intensif dan tahap lanjutan yang paling banyak diresepkan adalah fase intensif awal 3 tablet 4KDT dan 4 tablet 4KDT yaitu masing-masing sebanyak 4 peresepan $(18,18 \%)$, 3 tablet 4KDT artinya pasien TB sekali minum dalam 1 hari sebanyak 3 tablet dengan lama pengobatan selama 4 bulan dan 4 tablet 4KDT artinya adalah pasien TB sekali minum dalam sehari sebanyak 4 tablet dengan lama pengobatan selama 4 bulan, demikian pula pada fase lanjutan pemberian obat sekali minum sebanyak 3 tablet dengan lama pengobatan selama 2 bulan dan 4 tablet selama 2 bulan. Ada 4 jenis obat yang digunakan pada kategori 1 antara lain: rifampisin, isoniazid, etambutol serta pirazinamid. Hal ini sesuai dengan dosis yang diberikan kepada pasien yang menjadi sampel penelitian ini. Tidak ada overdosis maupun underdosis. ${ }^{13}$ Terapi tuberkulosis selalu diberikan dengan minimal 2 jenis obat atau lebih dengan tujuan untuk menncegah dan memperlambat terjadinya resistensi.(13)

Pada penggunaan obat TB dimasa pandemi Covid-19 sama halnya dengan penggunaan obat TB sebelum masa pandemi telah dilakukan paket dengan cara 
SANITAS: JURNAL TEKNOLOGI DAN SENI KESEHATAN

ISSN : 1978-8843 (PRINT) / 2615-8647 (ONLINE)

Vol. 12 (2), 2021 : 172 - 185

kombinasi dosis tetap dengan tujuan: mengurangi terjadinya kesalahan resep, lebih

tidak mengkonsumsi banyak tablet sehingga meminimalisir kehilangan obat, adanya dorongan untuk meningkatkan kepatuhan pengobatan. Namun dalam keterbatasan penggunaan KDT di masa pandemi Covid-19 dievaluasi antara lain: dapat terjadi kesalahan preskripsi obat, dosis sangat lebih berisiko toksisitas atau kadar sub inhibitor semua obat (dapat meningkatkan resiko timbul resistensi obat), jumlah tablet yang dimakan lebih sedikit keeefektifan rifampisin dengan nilai bioavaibiltas yang rendah terutama apabila FDC (fixed-dose combinations) dapat terjadi dengan kombinasi 3 atau 4 obat.(14)

Pada penelitian ini Pola KDT ketegori 2 terbanyak diresepkan pada fase awal intensif berupa 3 tablet $4 \mathrm{KDT}+750 \mathrm{mg}$ injeksi streptomisin, adapun pada fase lanjutan selama 2 bulan diberika pola peresepan 3 tablet 2KDT +3 tablet ethambutol.(15)

Keterbatasan penelitian disini, peneliti tidak sampai mengamati efek samping dan pengkajian interaksi obat dikarenakan keterbatasan waktu penelitian sehingga dapat dinilai secara teori. Terapi Antibiotik memiliki 2 kategori efek yang tidak diinginkan yaitu berupa efek samping minor (anoreksia, mual, nyeri abdomen, nyeri sendi, rasa terbakar pada kaki serta urin jingga/merah pada penggunaan rifampisin). Efek samping mayor sebagian kecil dapat terjadi yang meliputi: tuli, pusing, ikterus hepatitis, gangguan penglihatan serta syok. Adapun kesemua efek samping obat tuberkulosis perlu dikaji sesuai penatalaksanaan pengobatan tuberkulosis di Indonesia.(16) Pada penelitian ini telah terjadi resiko interaksi pengobatan secara farmakokinetika antara penggunaan obat paket TB paru (rifampisin) dengan osetalmivir dimana terdapat efek menurunkan metabolit aktif dari oseltamivir (lopinavir/ritonavir) dan sebaiknya untuk dfihindari penggunaan antiviral tersebut.(17)

Pada tabel 4 dapat diketahui bahwa obat-obatan untuk pasien Covid-19 yang paling sering diresepkan bersamaan dengan OAT adalah vitamin \& mineral sebanyak 56 peresepan $(42,42 \%)$. Pada Peresepan Multivitamin pasien mendapatkan obat multivitamin minimal 2-3 jenis obat, demikian pula pada peresepan antibiotik hampir keseluruhan pasien covid 100\% mendapatkan tambahan jenis antibiotik dengan pola peresepan 1-2 jenis obat per pasiennya.. Hal ini sejalan dengan penelitian Dini (2012) 
SANITAS: JURNAL TEKNOLOGI DAN SENI KESEHATAN

ISSN : 1978-8843 (PRINT) / 2615-8647 (ONLINE)

Vol. 12 (2), 2021 : 172 - 185

bahwa vitamin melindungi terhadap tuberkulosis telah didukung oleh in vitro, epidemiologi dan beberapa studi klinis awal.(18) Penggunaan terapi suportif pada pasien TB dengan status infeksi covid-19 perlu mendapatkan vitamin terutama vitamin yang memiki fungsi sebagai anti oksidan, seperti vitamin C dan Vitamin D.(19)

Penderita Tuberkulosis dengan status terinfeksi covid-19, pemberian antioksidan sangat memengaruhi penyembuhan penyakit melalui mekanisme perbaikan fungsi sel $\mathrm{T}$ dan menurunkan produksi prostaglandin E2 serta menekan efek radikal bebas.(20) Pada penderita TB yang mendapat antioksidan ditemukan status antioksidan meningkat dan terjadi penurunan stres oksidatif.(20) Contoh antioksidan yang sering digunakan adalah vitamin $\mathrm{C}$ yang berperan besar dalam memengaruhi fungsi imun dan pertahanan tubuh, serta melindungi lipid dari proses oksidasi. Vitamin C sebaiknya diberikan dalam waktu 14 hari supaya dapat meningkatkan kadar vitamin $\mathrm{C}$ dalam darah dan dapat meningkatkan kadar total antioksidan serum.(19)

Vitamin D memiliki metabolit aktif 1,25-dihidroksivitamin D (1,25[OH]2D) atau sering disebut Calcitriol. Calcitriol yang diketahui memiliki aktivitas antibiotik in vitro dengan cara memodulasi respon host terhadap infeksi mikrobakteria. Secara detail calcitriol mengaktifkan kembali nitrogen dan oksigen, menghambat aktivitas dari Metaloproteinase Matrix (MMP) yang berperan dalam proses pembentukan kavitas dan menginduksi autofagi.(21) Kavitas merupakan kantung tidak normal yang terbentuk di dalam paru-paru akibat infeksi seperti tuberkulosis atau tumor.(22) Autophagy diketahui mempunyai peran penting untuk proses eliminasi dan daur ulang protein dan organel yang rusak.(23)

Selain multivitamin terapi supotif pada pasien tuberkulosis yang terinfeksi Covid-19 adalah penggunaan antibiotik, dari penelitian ini terlihat bahwa dokter dalam merepkan antibiotik minimal 1-2 jenis obat non FDC. Hal inilah perlu pengkajian terapi penggunaan obat terutama interaksi obat sesama antibiotik yang digunakan. Namun dengan keterbatasan penelitian selama pandemi Covid-19 maka pengkajian belum dapat terlaksana dan menjadi saran dengan peneliti lain untuk dilakukan pengkajian peresepan ada atau tidaknya interaksi obat.(24) 
SANITAS: JURNAL TEKNOLOGI DAN SENI KESEHATAN

ISSN : 1978-8843 (PRINT) / 2615-8647 (ONLINE)

Vol. 12 (2), 2021 : 172 - 185

Untuk kelas terapi Antibiotik terbanyak yang digunakan adalah levofloxacin.

Levofloxacin merupakan terapi alternatif antibiotik yang diberikan kepada pasien Covid-19 selain azithromycin. Lalu untuk antivirus yang paling banyak digunakan adalah oseltamivir. Hal ini sejalan dengan sebuah studi kasus di Taiwan yang menunjukkan penggunaan oseltamivir untuk Covid-19. Oseltamivir diberikan sejak hari pertama mendapatkan perawatan di rumah sakit yang umumnya dikombinasikan dengan penggunaan levofloksasin.(25) Berdasarkan ketersediaan obat di Indonesia, oseltamivir mulai digunakan pada fase awal pandemic Covid-19, Namun dari hasil penelitian, saat ini oseltamivir tidak cocok untuk pengobatan Covid-19, sehingga Kementrian Kesehatan mengeluarkan buku saku, bahwa oseltamivir digunakan terutama diduga ada infeksi antiinfluenza.(26)

Rasionalisasi dari penggunaan Levofloxacin pada Covid-19 nampaknya mengacu kepada pengalaman kejadian superinfeksi bakteri seperti pada infeksi influenza, dimana 11-35\% kasus influenza yang dirawat terbukti mengalami ko-infeksi bakteri sekunder inisial yang umumnya disebabkan oleh infeksi bakteri Streptococcus pneumoniae dan Staphylococcus aureus. Infeksi virus di saluran pernapasan sendiri dikatakan dapat menjadi faktor predisposisi dari koinfeksi bakteri maupun jamur yang pada akhirnya dapat berakibat buruk terhadap derajat keparahan hingga kematian.(27)

Kelas terapi selanjutnya yang digunakan pada pasien TB dengan komorbid Covid-19 adalah obat lambung. Obat lambung yang paling sering diresepkan adalah Omeprazole, Omeprazole merupakan golongan PPI (Proton Pump Inhibitor). PPI diberikan pada indikasi yang sesuai dengan menggunakan dosis efektif terendah, untuk mencapai kontrol pH lambung dan kualitas hidup yang baik pada pasien GERD (Gastroesophageal reflux disease).(19)

Penggunaan kelas terapi terakhir yang paling banyak diresepkan untuk pasien TB dengan komorbid Covid-19 adalah analgetik. Analgetik yang paling sering digunakan adalah paracetamol. Pada terapi Covid-19, paracetamol berfungsi sebagai terapi simptomatik seperti penurun demam yang disertai flu dan untuk meringankan rasa nyeri seperti nyeri di kepala, gigi atau di otot.(20) 


\section{SIMPULAN}

Hasil pengobatan TB Paru pada pasien rawat inap dengan status riwayat Covid19 di RSUD Pasar Minggu terdapat proporsi kesesuaian pola peresepan berdasarkan protokol Kemenkes RI sebesar 100\%. Kombinasi OAT yang paling banyak diresepkan adalah KDT kategori 2 (54,55\%). Jenis terapi untuk pasien Covid-19 yang paling sering diresepkan bersamaan dengan OAT yaitu vitamin dan mineral sebanyak $42,42 \%$.

\section{UCAPAN TERIMAKASIH}

Penulis berterima kasih kepada seluruh civitas akademika Poltekkes Kemenkes Jakarta III. Selanjutnya terima kasih kepada RSUD Pasar Minggu yang telah memberikan izin dalam pengambilan data penelitian ini, serta seluruh pihak yang telah berkontribusi dalam penelitian ini.

\section{DAFTAR PUSTAKA}

1. Wang C, Horby PW, Hayden FG, Gao GF. A novel coronavirus outbreak of global health concern. The Lancet. 2020.

2. Alfaraj SH, Al-Tawfiq JA, Altuwaijri TA, Memish ZA. Middle East Respiratory Syndrome Coronavirus and Pulmonary Tuberculosis Coinfection: Implications for Infection Control. Intervirology. 2017;60(1-2):53-5.

3. Migliori GB, Tiberi S, Zumla A, Petersen E, Chakaya JM, Wejse C, et al. MDR/XDR-TB management of patients and contacts: Challenges facing the new decade. The 2020 clinical update by the Global Tuberculosis Network. Int J Infect Dis. 2020;92:S15-25.

4. World Health Organization. Tuberculosis deaths rise for the first time in more than a decade due to the COVID-19 pandemic [Internet]. World Health Organization. 2021 [cited 2021 Oct 16]. Available from: https://www.who.int/news/item/14-10-2021-tuberculosis-deaths-rise-for-thefirst-time-in-more-than-a-decade-due-to-the-covid-19-pandemic

5. Soares VM, de Almeida IN, Figueredo LJ de A, Haddad JPA, de Oliveira CSF, Carvalho $\mathrm{W}$ da $\mathrm{S}$, et al. Factors associated with tuberculosis and multidrugresistant tuberculosis in patients treated at a tertiary referral hospital in the state of Minas Gerais, Brazil. J Bras Pneumol. 2020;46(2).

6. Lopes ARV, Miranda SS DE, Ceccato MDGB, Silvera MR, Resende NH DE, Carvalho WS. Evaluation of the impact of pharmaceutical care for tuberculosis patients in a Secondary Referral Outpatient Clinic, Minas Gerais, Brazil. An Acad Bras Cienc. 2017 Dec;89(4):2911-9.

7. Kemenkes RI. Pedoman Penanggulanagn Tuberkulosis (TB) 2009; 
SANITAS: JURNAL TEKNOLOGI DAN SENI KESEHATAN

ISSN : 1978-8843 (PRINT) / 2615-8647 (ONLINE)

Vol. $12(2), 2021: 172$ - 185

8. Gao Y, Liu M, Chen Y, Shi S, Geng J, Tian J. Association between tuberculosis and COVID-19 severity and mortality: A rapid systematic review and metaanalysis. Journal of Medical Virology. 2021.

9. Wan S, Xiang Y, Fang W, Zheng Y, Li B, Hu Y, et al. Clinical features and treatment of COVID-19 patients in northeast Chongqing. J Med Virol. 2020;

10. Siagian TH. Corona Dengan Discourse Network Analysis. J Kebijak Kesehat Indones. 2020;09(02):98-106.

11. Kemenkes RI. Strategi Nasional Pengendalian Tuberkulosis. Direktorat Jenderal Pengendali Penyakit dan Penyehatan Lingkung. 2014;

12. Kemenkes RI. Protokol Pelayanan tentang Tuberkulosis/TBC Selama Masa Pandemi Covid 19 [Internet]. Direktorat Jenderal Pencegahan dan Pengendalian Penyakit Kementerian Kesehatan RI. 2020 [cited 2021 Aug 16]. Available from: https://infeksiemerging.kemkes.go.id/download/Protokol_Tentang_Pelayanan_ TBC_selama_masa_Pandemi_Covid_19.pdf

13. Kamso PS, Manaf A, Alamiahnya R, Tuberkulosis UP, Tuberkulosis P, Mutu P, et al. Pedoman Nasional Penanggulangan Tuberkulosis edisi 2. Pedoman Nas Penanggulangan Tuberkulosis Ed 2. 2011;

14. Nurafni S, Sari N, Mulyani F. Comparison of Drug Induced Hepatotoxicity Incident of Fixed-Dose Combination and Separate Formulations Regimen for Pulmonary Tuberculosis Treatment in Hospital Sukabumi. J Phys Conf Ser. 2021 Feb 1;1764(1):012012.

15. Kementerian Kesehatan RI. Pedoman Nasional Pengendalian Tuberkulosis. Jakarta; 2014.

16. Kemenkes RI. Pedoman Nasional Pengendalian Tuberkulosis. Kementeri Kesehat Republik Indones. 2011;(Pengendalian Tuberkulosis):110.

17. Faizah AKNN; PON. A Mini Review : Clinically Significant Potential DrugDrug Interactions In COVID-19 and Comorbid Therapy. Pharm Sci Res. 2020;7(Special Issue on COVID-19):23-8.

18. Dini C, Bianchi A. The potential role of vitamin D for prevention and treatment of tuberculosis and infectious diseases. Ann Ist Super Sanita. 2012 Sep;48(3):319-27.

19. Zakiyyah ER, Gurnida DA, Kartasasmita CB. Pengaruh Pemberian Vitamin C terhadap Perubahan Kadar Total Antioksidan Serum pada Penderita Tuberkulosis Paru Anak. Sari Pediatr. 2016 Nov 9;16(2):110.

20. Seyedrezazadeh E, OstadrahimiA, Mahboob S, Assadi Y, Ghaemmagami J, Pourmogaddam M. Effect of vitamin E and selenium supplementation on oxidative stress status in pulmonary tuberculosis patients. Respirology. 2008 Mar;13(2):294-8.

21. Hassanein EG, Mohamed EE, Baess AI, EL-Sayed ET, Yossef AM. The role of supplementary vitamin D in treatment course of pulmonary tuberculosis. Egypt J Chest Dis Tuberc. 2016 Jul;65(3):629-35.

22. Redaksi Halodoc. Ketahui Penanganan Pneumotoraks Berdasar Tingkat Keparahannya. 2019.

23. Pratiwi YS, Lesmana R, Setiawan S, Purba A. Autophagy dan Sarkopenia. Syifa' Med J Kedokt dan Kesehat. 2019;10(1):31. 
SANITAS: JURNAL TEKNOLOGI DAN SENI KESEHATAN

ISSN : 1978-8843 (PRINT) / 2615-8647 (ONLINE)

Vol. $12(2), 2021: 172$ - 185

24. Davies PDO. Multi-drug resistant tuberculosis. CPD Infect. 2002;3(1):9-12.

25. Liu Y-C, Liao C-H, Chang C-F, Chou C-C, Lin Y-R. A Locally Transmitted Case of SARS-CoV-2 Infection in Taiwan. Vol. 382, The New England journal of medicine. 2020. p. 1070-2.

26. Setiadi AP, Wibowo YI, Halim S V., Brata C, Presley B, Setiawan E. Tata Laksana Terapi Pasien dengan COVID-19: Sebuah Kajian Naratif. Indones J Clin Pharm. 2020;9(1):70.

27. Kemenkes RI. Pedoman Tatalaksana Covid-19. 2020. 1-112 p. 